\title{
Risk of cancer in first seven years after metal-on-metal hip replacement compared with other bearings and general population: linkage study between the National Joint Registry of England and Wales and hospital episode statistics
}

\author{
(c) $(1)$ (8)
}

\author{
Alison J Smith statistician ${ }^{1}$, Paul Dieppe chair of clinical education research ${ }^{2}$, Martyn Porter consultant \\ orthopaedic surgeon $^{3}$, Ashley W Blom professor and head of orthopaedic surgery ${ }^{1}$, on behalf of \\ the National Joint Registry of England and Wales
}

\begin{abstract}
${ }^{1}$ Musculosketal Research Unit, School of Clinical Sciences, University of Bristol, Avon Orthopaedic Centre, Bristol BS10 5NB, UK; ${ }^{2}$ Peninsula Medical School, Universities of Plymouth and Exeter, University of Exeter, Exeter EX1 2LU; ${ }^{3}$ Centre for Hip Surgery, Wrightington Hospital, Wigan,
\end{abstract} Lancashire WN6 9EP

\begin{abstract}
Objective To determine whether use of metal-on-metal bearing surfaces is associated with an increased risk of a diagnosis of cancer in the early years after total hip replacement and specifically with an increase in malignant melanoma and haematological, prostate, and renal tract cancers.

Design Linkage study with multivariable competing risks flexible parametric survival model to examine the incidence of new diagnoses of cancer in patients with metal-on-metal hip replacement compared with those with alternative bearings and to compare the observed incidence of diagnoses in patients undergoing hip replacement with that predicted by national incidence rates in the general population.

Setting National Joint Registry of England and Wales (NJR) linked to NHS hospital episode statistics data.

Participants 40576 patients with hip replacement with metal-on-metal bearing surfaces and 248995 with alternative bearings.

Main outcome measures Incidence of all cancers and incidence of malignant melanoma and prostate, renal tract, and haematological cancers.

Results The incidence of new diagnoses of cancer was low after hip replacement (1.25\% at one year, 95\% confidence interval $1.21 \%$ to $1.30 \%$ ) and lower than that predicted from the age and sex matched normal population (1.65\%, $1.60 \%$ to $1.70 \%)$. Compared with alternative bearings, there was no evidence that metal-on-metal bearing surfaces were associated with an increased risk of any cancer diagnosis in the seven years after surgery (mean follow-up of three years, $23 \%$ ( $n=67$ 361 ) of patients observed for five years or more). Similarly, there was no increase in the risk of malignant melanoma or haematological,
\end{abstract}

prostate, and renal tract cancers. The adjusted five year incidence of all cancers for men aged 60 was $4.8 \%$ (4.4\% to $5.3 \%$ ) with resurfacing, $6.2 \%(5.7 \%$ to $6.7 \%)$ with stemmed metal-on-metal, and $6.7 \%(6.5 \%$ to $7.0 \%)$ for other bearing surfaces. Equivalent rates for women aged 60 were lower: $3.1 \%(2.8 \%$ to $3.4 \%)$ with resurfacing, $4.0 \%(3.7 \%$ to $4.3 \%)$ with stemmed metal-on-metal, and $4.4 \%(4.2 \%$ to $4.5 \%)$ with other bearings.

Conclusions These data are reassuring, but the findings are observational with short follow-up. The use of hospital episode statistics data might underestimate cancer diagnoses, and there is the possibility of confounding by indication. Furthermore, as some cancers have a long latency period it is important that we study the longer term outcomes and continue to investigate the effects of exposure to orthopaedic metals.

\section{Introduction}

Metal-on-metal total hip replacement has become popular over the past decade and now accounts for $35 \%$ of hip replacements in the United States ${ }^{1}$ and $14 \%$ of hip replacements recorded on the National Joint Registry of England and Wales. ${ }^{2}$ Of those recorded on the National Joint Registry, about half are stemmed hip replacements and half are resurfacing procedures. Large diameter metal-on-metal bearing surfaces have the potential advantages of lower wear ${ }^{3}$ and lower rates of dislocation. ${ }^{4}$ Recent data from the National Joint Registry, however, has shown a significantly higher failure rate with stemmed metal-on-metal ${ }^{5}$ and an above average failure rate with hip resurfacing. ${ }^{2}$ In addition, little is known of the biological effects of the metals-predominantly cobalt, chromium, and molybdenum - that are released into the body by these implants. 
After hip replacement, metal particles disseminate throughout the body and can be found in many organs including marrow, blood, liver, kidneys, and bladder. ${ }^{6}$ Patients who have undergone joint replacements have a higher than normal incidence of DNA damage to blood lymphocytes. ${ }^{8}$ In concentrations found in the blood after hip replacement, cobalt and chrome have the ability to signal across intact barriers in the body and cause irreversible DNA changes to cells on the other side of the barrier. ${ }^{9}$ This calls into question the protective ability of the placenta and blood-brain barrier.

A long history of occupational research has found that high exposure to metal ions is associated with an increased incidence of certain cancers. ${ }^{10}$ Therefore, researchers have queried whether metal exposure from hip replacements could also lead to the development of cancers. A 2006 meta-analysis found higher rates of prostate cancer and melanomas in patients after hip replacement than among the wider population. It also found that the risk of renal tract cancers (affecting the bladder, ureter, and kidney) increased over time for such patients, possibly through urinary excretion of metals. ${ }^{11}$ Furthermore, a Swedish study has shown that patients with osteoarthritis and rheumatoid arthritis who have undergone knee replacement are at greater risk of developing some haematological malignancies and are possibly at greater risk of developing prostate cancer and malignant melanoma. $^{12}$

Detection of any increased risk of cancer requires a suitable population with which to compare patients with metal-on-metal articulations. Comparison with the general population is not straightforward because, on average, patients who undergo hip replacement tend to be healthier than others of the same sex and age group. For instance, the National Joint Registry's eighth annual report found that observed mortality after joint replacement was lower than that among the comparable wider population. ${ }^{2}$ Therefore, a more suitable comparison group is patients with other types of hip replacement. We used the data from the National Joint Registry linked to NHS hospital episodes statistics data to test the hypothesis that the use of metal-on-metal bearing surfaces is associated with an increased risk of being diagnosed with cancer in the early years after hip replacement compared with other bearing surfaces.

\section{Methods}

\section{Data sources}

The National Joint Registry of England and Wales was established in 2003 and is the largest arthroplasty database in the world. It records all primary and revision hip and knee replacements undertaken in England and Wales, including NHS and independently funded operations. By April 2011, it contained records of 1082465 procedures. ${ }^{2}$ Coverage has improved steadily since 2003 with $97 \%$ of orthopaedic units submitting data in 2010. Data collection forms are completed by surgeons at the time of operation and submitted by hospital staff supported by regional coordinators. The hospital episode statistics database is the primary source of NHS inpatient data and contains details of all admissions to NHS hospitals in England, including private patients treated in NHS hospitals, patients who were living outside England, and care delivered by treatment centres and private hospitals funded by the NHS. Hospital episode statistics are based on medical records assessed by NHS clinical coding staff.

Every year, the National Joint Registry routinely links registry data and hospital episode statistics data to check data and to use the wider health information in hospital episode statistics relating to joint replacement patients. As hospital episode statistics contains details only on NHS funded admissions in England, around 14\% of National Joint Registry cases (relating to independently funded operations in England and operations in Wales) cannot be linked to hospital episode statistics. In addition, $17 \%$ of joint registry records do not contain person level identifiers that allow linkage to hospital episode statistics, usually because the patient did not give consent for data linkage and for their personal details to be held. ${ }^{2}$ When data linkage should be possible, $6 \%$ of registry hip replacements could not be matched to hospital episode statistics. Characteristics of the patients that could not be matched (including the independently funded patients) were not dissimilar to those shown in table $1 \Downarrow$ for linked patients (mean age 66.9, 42\% men, mean American Society of Anaesthesiologists (ASA) grade 1.8). We have used the most recent linked data here: patients in England who underwent hip replacement from 1 April 2003 to 31 December 2010 and for whom National Joint Registry data could be linked to hospital episode statistics data $(n=289571)$.

\section{Outcome measures}

Hospital episode statistics data for all hospital admissions for these patients between 1997 (the earliest time that such data can be obtained) and 2010 has been used and the relevant ICD-10 (international classification of diseases, 10th revision) diagnosis codes have been used to define these conditions. This method cannot precisely identify the time of diagnosis (as the initial diagnosis might not have been associated with a hospital admission in this period), but when there were multiple hospital episodes for a patient, we chose the earliest date of any hospital admission with the relevant diagnosis code.

We focused our main analysis on the risk of receiving a diagnosis of any type of cancer in the years after hip replacement, including all forms of cancer other than non-melanoma skin cancers. The relevant ICD-10 codes are C00-C97 (malignant neoplasms) and D00-D09 (carcinoma in situ), excluding C44 (non-melanoma skin cancers). We also individually considered some specific types of cancer that are suspected of being related to metal ions, giving five sets of analyses: any type of cancer, haematological cancers (such as lymphoma, leukaemia, or myeloma), malignant melanoma, prostate cancer (for men only), and renal cancer (bladder, ureter, or kidney).

For each outcome, patients who had a recorded diagnosis of that condition before, or at the time of, their hip replacement were excluded from the analysis. These patients were not excluded for the diagnosis of other cancers.

\section{Statistical analysis}

We compared patients with metal-on-metal hip replacements (both stemmed hip replacements and resurfacing hip arthroplasty) with two groups: the general population and patients with hip replacement with other bearing surfaces. Given the large sample size, small differences can have $\mathrm{P}$ values of less than $0.05^{13}$ so for all analyses we present $95 \%$ confidence intervals to indicate the range of any likely difference between the groups.

\section{Comparison with the general population}

We used the Nelson-Aalen cumulative hazard function from survival analysis to estimate unadjusted observed incidence rates for a diagnosis of cancer after hip replacement. The expected incidence is calculated by applying the age and sex specific national cancer incidence rates (collated from cancer registries and published by the Office for National Statistics ${ }^{14}$ ) 
to the hip replacement population considered here. We assumed a Poisson distribution to calculate the $95 \%$ confidence intervals for the expected rates.

\section{Comparison with alternative bearing surfaces}

We separated patients into three groups: those with stemmed metal-on-metal, those with resurfacing arthroplasty, and total hip replacements with other bearing surfaces. As the patients are selected for and not randomised to different surgical options, we used multivariable analysis to adjust for the systematic differences between groups of patients (table 1). $\Downarrow$ In addition, as we are observing a relatively elderly population, the risk of death in the years after joint replacement is not insignificant and ignoring it could bias the analysis. ${ }^{2}$ To adjust for this competing risk, we used a multivariable flexible parametric survival mode ${ }^{15}$ to estimate the cumulative incidence of cancer diagnosis in the presence of the competing risk of death. ${ }^{16}$ This method models the effect of the covariates both on the risk of having a diagnosis of cancer (the main risk) and on the risk of death (the competing risk). The effects of the covariates have been allowed to vary for the main and competing risks. All models control for the age and sex of the patient. In addition, we used three proxy measures of general health at the time of primary surgery. The first is the American Society of Anaesthesiologists (ASA) grade, a measure of serious comorbidities assessed by the anaesthetist at the time of primary surgery and recorded in the National Joint Registry. Two other measures were calculated from the hospital episode statistics data: the number of distinct ICD-10 diagnosis codes recorded at time of surgery (a proxy measure of the number of different comorbidities) and the number of NHS funded admissions to hospital in the previous five years (a proxy measure of health status over time).

These models produce hazard ratios, which are a measure of relative risk (averaged over time). To illustrate the absolute effect of these factors, we used the models to predict incidence rates for a typical patient by estimating the cumulative incidence function adjusted for covariates in the presence of competing risks. Values of covariates are held constant at factors around the average (for the proxy measures of health) and by choosing a value of age that has large enough numbers in all patient groups to ensure robust estimation.

For the multivariable models, we assessed proportionality of hazards by testing, for individual covariates and globally, the null hypothesis of zero slope, which is equivalent to testing that the log hazard ratio function is constant over time. Log-log plots were also assessed. We found no major violations of the proportional hazards assumption. Model fit was assessed by examining the Cox-Snell residuals and deviance residuals, which indicated no outliers or any other cause for concern. We undertook a sensitivity analysis to check whether clustering by implant brand affected the results. The standard errors of a standard Cox proportional hazards model were adjusted for the clustering by brand to allow for intragroup correlation. This did not significantly change the results, probably because many brands of implants were used, particularly in stemmed procedures where different combinations of stems and cups can be used (there were 216 implant types that had been used in at least 100 patients).

\section{Results}

Overall, 14\% (40 576) of patients had some type of metal-on-metal bearing surface: $7 \%(n=21264)$ had a stemmed metal-on-metal prosthesis and $7 \%(\mathrm{n}=19312)$ had a resurfacing procedure. The use of metal-on-metal has varied over time. Resurfacing procedures formed $7 \%$ of all hip replacements in 2003 rising to $9 \%$ in 2005 and 2006 and falling to 3\% by 2010 . Stemmed metal-on-metal formed just $2 \%$ of hip replacements in 2003 , rising to a peak of $11 \%$ in 2008 , and falling to $4 \%$ in 2010. This increase in stemmed metal-on-metal was almost entirely because of the use of large head sizes. ${ }^{5}$ Table 1 shows the sociodemographic characteristics of the three hip replacement groups $\Downarrow$. There were substantial differences between the groups, with the resurfacing group in particular being much younger and healthier than the other groups.

The mean length of time since surgery was 3.0 years (median 2.8 years) with $83 \%$ of patients having been observed for at least one year and $23 \%$ for between five and eight years. Table 2 lists the diagnoses of cancers in this time period, $\Downarrow$ and shows that $1.25 \%$ of all patients were diagnosed with some type of cancer within one year of their surgery. Annual incidence rates tended to be similar with each additional year after surgery, although they increased slightly as the patients became older. By five years, $8 \%$ had had a diagnosis of any type of cancer and by seven years it was $11 \%$. Diagnosis of the more specific cancers was rarer (table 2) $\downarrow$.

\section{Comparison with the general population}

Based on national cancer incidence rates, the expected one year incidence of cancer for the hip replacement sample was $1.65 \%$ (95\% confidence interval $1.60 \%$ to $1.70 \%$ ). A comparison of one year observed diagnosis rates with expected rates showed that men and women with all types of hip replacement were less likely to receive a diagnosis of cancer than an age and sex matched general population (table $3 \Downarrow$ ). Patients with metal-on-metal bearing surfaces had lower observed incidence rates than those with other bearing surfaces, with a particularly low rate in younger patients in the resurfacing metal-on-metal group.

\section{Comparison with alternative bearing surfaces}

Compared with other types of hip replacement, the multivariable statistical models found no evidence that having a stemmed metal-on-metal hip replacement or a resurfacing procedure was associated with an increased risk of cancer diagnosis in this time period (table $4 \Downarrow$ ). The competing risks models also showed that having a metal-on-metal bearing surface was not associated with an increased risk of death (table $5 \Downarrow$ ).

In fact, there was a suggestion of a slight decrease in the risk of any cancer diagnosis associated with metal-on-metal bearing surfaces. The models indicated that patients who underwent resurfacing procedures were less likely than those with other bearing surfaces to get a diagnosis of prostate cancer, haematological cancers, or any cancer (table $4 \Downarrow$ ). They also had a lower risk of death across all models than patients with other bearing surfaces (table 5) $\Downarrow$. For stemmed metal-on-metal bearing surfaces, the hazard ratio for diagnosis of any type of cancer was 0.92 , but the $95 \%$ confidence interval was 0.85 to 1.00 suggesting that if there was any reduction in risk it was small. Generally, the other factors in the model were significant predictors of the risk of cancer diagnosis in all models (table 4 ) $\Downarrow$. Increasing age was associated with an increased risk of cancer diagnosis for all models. Men were more likely than women to get a diagnosis of renal cancer, melanoma cancer, haematological cancers, and any cancer. Increases in ASA grade, number of diagnosis codes, and number of previous admissions were also predictors of an increased risk of cancer diagnosis for all models except for melanoma. All of these factors were strong 
and significant predictors of the competing risk of death in all models (table 5) $\Downarrow$.

Table 6 shows adjusted incidence rates for any type of cancer for a typical patient aged $60 . \Downarrow$ This analysis shows a relatively small reduction in the risk of cancer diagnosis for patients undergoing resurfacing procedures, smaller than that observed in the unadjusted analysis in table 3 . Generally, the differences between men and women are larger than those between the groups with different types of hip replacement.

\section{Discussion}

\section{Main findings}

Despite the theoretical risks, we did not find a link between metal-on-metal hip replacements (either stemmed or resurfacing) and increased incidence of cancer diagnosis. The incidence of cancer diagnosis is low after hip replacement and is lower than that predicted for the age and sex matched general population. Furthermore, our models indicated that patients undergoing resurfacing procedures were less likely than those with alternative bearings to get a diagnosis of prostate cancer, haematological cancers, or any cancer and had a lower risk of death.

\section{Strengths and weaknesses of the study}

We analysed a large representative sample of patients with hip replacement and so can have some confidence in the findings for the period studied. Despite this confidence, we cannot extrapolate these findings into the long term as some cancers have a prolonged latency and thus will require an analysis of long term data over the next few decades when these becomes available.

The method of using data from hospital episode statistics to identify cancer is likely to underestimate diagnoses as a minority of patients might receive a diagnosis and be treated without any inpatient admission. Such data also affect our ability to identify the exact time of diagnosis. There is no reason to think, however, that the underestimation of cancer rates or that any uncertainty around time of diagnosis will differ by the type of joint replacement a patient had. Therefore, it is unlikely to affect the overall comparison being made here between metal-on-metal prostheses and other bearing surfaces. Registry data from other countries confirms that patients' demographics and disease profiles are similar as are the implants used, ${ }^{17}$ but incidences of cancer do differ globally according to factors such as environmental exposure, genetics, and lifestyle. ${ }^{18}$ As such, the extent to which these results are generalisable to healthcare systems outside the United Kingdom will vary. Hip replacement patients are not routinely screened for cancers. It is likely that a targeted screening programme would identify more patients with cancer than we have identified here. Furthermore, certain at risk subgroups might be more susceptible to developing cancer after exposure to these metals. The analysis reported here would be unlikely to identify this unless the size of the subgroup, or the magnitude of the effect, was large.

The difficulty of finding a suitable population with which to compare patients with metal-on-metal articulations remains. That the analysis found a reduced incidence of certain cancers in patients with metal-on-metal bearing surfaces is not easy to explain and could reflect a "well patient" effect and the difficulties of adequately measuring and controlling for differences in general health and wellbeing. In particular, the comparison between patients undergoing resurfacing procedures and those with other bearing surfaces is not straightforward. As well as undergoing a different surgical procedure, patients undergoing resurfacing procedures tend to be much younger and more active than other hip replacement patients and are usually selected for the alternative resurfacing procedure for precisely these reasons. Similarly, it is possible that there are differences in the groups of patients who have stemmed metal-on-metal prostheses and those with other bearing surfaces, resulting in confounding by indication.

While data from randomised controlled trials would be preferable to observational data in terms of reducing confounding, the sample sizes would not be large enough to detect the relatively rare incidence of cancer. In addition, as all joint replacements produce some metal debris, even if the bearing surfaces are not metal, it would be prudent to compare them with a control group of patients without joint replacements. The control group would also need to have osteoarthritis as this is associated with lower rates of cancer. ${ }^{19}$ This comparison could again be difficult because of a "well patient" effect as patients who have undergone total joint replacement have been shown to have a lower mortality from all cause ${ }^{20}$ and, in this analysis, a lower incidence of cancer than the general population. People of lower socioeconomic status are less likely to be offered joint replacement, ${ }^{21}$ and lower socioeconomic status is associated with cancer.

\section{Comparison with existing literature}

Visuri and colleagues performed a meta-analysis of studies comparing the risk of developing cancer in patients with joint replacements with the normal population and found a lower risk. ${ }^{22} \mathrm{We}$ found the same. The meta-analysis by Onega and colleagues compared the incidence of 28 cancers between those receiving hip or knee replacement and the general population. ${ }^{11}$ They found no increase in overall incidence of cancers, but an increase in prostate cancer and malignant melanoma. The increase in malignant melanoma became apparent only after 10 year follow-up. Occupational exposure to metals typically has a long latency before the development of cancers. ${ }^{23}$ As our maximum follow-up was around seven years, we would not detect cancers with a longer latency period. Visuri et al also studied mortality after metal-on-metal and

metal-on-polyethylene hip replacement in a Finnish cohort of 2164 patients with over 16 years' mean follow-up. ${ }^{24}$ Although both bearing surfaces were associated with lower overall mortality than the normal population, those with metal-on-metal bearing surfaces had a higher mortality from cancer than those with metal-on-polyethylene hips for the first 20 years after surgery, but not thereafter. Because of our short follow-up we have not considered mortality from cancer.

Some studies have shown an association between blood cobalt and chromium concentrations and increased failure after metal-on-metal hip replacements. ${ }^{25}{ }^{26}$ Cobalt and chrome have been shown to be genotoxic, but it is unclear whether this is a dose dependent or threshold effect and it is also unclear whether cobalt and chrome work synergistically in producing genotoxicity. ${ }^{9}$ This work suggests that any genotoxicity is not translated into an increase in cancers in the entire population in the time period studied. At risk groups, however, such as those with high serum concentrations of metal ions, warrant further investigation.

\section{Conclusions and implications for further research}

The recent media coverage of metal-on-metal hip replacements is likely to have increased fears among patients in England and 
Wales with these implants, currently around 70000 people. Although these data are observational and we do not have long term follow-up data, they can help clinicians to reassure patients that the risk of cancer after hip replacement is relatively low and that there is no evidence of an increase in cancer associated with metal-on-metal bearing surfaces in the seven years after surgery. To determine whether metal-on-metal hip replacements are associated with an increased risk of cancer in the long term, however, we need more longitudinal data as well as more research to help determine the biological consequences of metal exposure and thereby provide a strong theoretical basis to predict which cancers might arise. We can then screen for any predicted cancers. The analysis reported here will need to be repeated in the future with a longer follow-up of the National Joint Registry-hospital episode statistics linked data. In the meantime, we need to link such data to the national cancer registries to obtain a more complete picture of an evolving topic.

We thank the patients and staff of all the hospitals who have contributed data to the National Joint Registry. We are grateful to the Healthcare Quality Improvement Partnership, the National Joint Registry Steering Committee, and staff at the NJR Centre for facilitating this work. The views expressed represent those of the authors and do not necessarily reflect those of the National Joint Registry Steering Committee or the Health Quality Improvement Partnership who do not vouch for how the information is presented. We are grateful to Emma Clark for her assistance.

Contributors: AJS undertook the data analysis, designed the study, interpreted the data, and drafted the paper. PD designed the study, interpreted the data, and drafted the paper. MP drafted the paper. AWB undertook the literature review, designed the study, interpreted the data, and drafted the paper. AWB is guarantor.

Funding: This study was funded by the National Joint Registry for England and Wales Steering Committee (NJRSC) as one of several specialist topic areas included in its ongoing work programme. MP is a member of the NJRSC and is chair of the Editorial Board. Decisions over the design, data analysis, and data interpretation were made independently by the authors. The decision to submit for publication was made by AWB.

Competing interests: All authors have completed the ICMJE uniform disclosure form at www.icmje.org/coi_disclosure.pdf (available on request from the corresponding author) and declare: MP receives royalties from the manufacturer DePuy for a cemented hip prosthesis. Ethical approval: Not required.

Data sharing: Access to data is available from the National Joint Registry for England and Wales.

1 Bozic KJ, Ong K, Lau E, Kurtz SM, Vail TP, Rubash HE, et al. Risk of complication and revision total hip arthroplasty among Medicare patients with different bearing surfaces. Clin Orthop Relat Res 2010;468:2357-62.

2 National Joint Registry for England and Wales. 8th annual report. NJR, 2011.

3 Dowson D, Hardaker C, Flett M, Isaac GH. A hip joint simulator study of the performance of metal-on-metal joints. Part ii: design. J Arthroplasty 2004;19(suppl 3):124-30.
4 Jameson SS, Lees D, James P, Serrano-Pedraza I, Partington PF, Muller SD, et al. Lower rates of dislocation with increased femoral head size after primary total hip replacement: 5-year analysis of NHS patients in England. J Bone Joint Surg (Br) 2011;93:876-80.

5 Smith AJ, Dieppe P, Vernon K, Porter M, Blom AW. Failure rates of stemmed metal-on-metal hip replacements: Analysis of data from the National Joint Registry of England and Wales. Lancet 2012 Mar 12 [epub ahead of print].

6 Keegan GM, Learmonth ID, Case CP. A systematic comparison of the actual, potential, and theoretical health effects of cobalt and chromium exposures from industry and surgical implants. Crit Rev Toxicol 2008;38:645-74.

7 Case CP, Langkamer VG, James C, Palmer MR, Kemp AJ, Heap PF, et al. Widespread dissemination of metal debris from implants. J Bone Joint Surg (Br) 1994;76:701-12.

8 Doherty AT, Howell RT, Ellis LA, Bisbinas I, Learmonth ID, Newson R, et al. Increased chromosome translocations and aneuploidy in peripheral blood lymphocytes of patients having revision arthroplasty of the hip. J Bone Joint Surg Br 2001;83:1075-81.

9 Parry MC, Bhabra G, Sood A, Machado F, Cartwright L, Saunders M, et al. Thresholds for indirect DNA damage across cellular barriers for orthopaedic biomaterials. Biomaterials 2010;31:4477-83.

10 Keegan GM, Learmonth ID, Case CP. Orthopaedic metals and their potential toxicity in the arthroplasty patient. A review of current knowledge and future strategies. J Bone Joint Surg 2007;89:567-73.

11 Onega T, Baron J, MacKenzie T. Cancer after total joint arthroplasty: a meta-analysis. Cancer Epidemiol Biomarkers Prev 2006;15:1532-7.

12 Wagner P, Olsson H, Lidgren L, Robertsson O, Ranstam J. Increased cancer risks among arthroplasty patients: 30 year follow-up of the Swedish Knee Arthroplasty Register. Eur J Cancer 2011;47:1061-71.

13 Gardner, MJ, Altman, DG. Confidence intervals rather than $P$ values: estimation rather than hypothesis testing. BMJ 1986;292:746.

14 Office for National Statistics. Cancer statistics registrations: registrations of cancer diagnosed in 2009, England. ONS, 2011 www.ons.gov.uk/ons/rel/vsob1/cancer-statisticsregistrations--england--series-mb1-/no--40--2009/cancer-registrations-2009.xls.

15 Royston P, Parmar MKB. Flexible proportional-hazards and proportional-odds models for censored survival data, with application to prognostic modelling and estimation of treatment effects. Stat Med 2002 21:2175-97.

16 Coviello, E. STCOMPADJ: Stata module to estimate the covariate-adjusted cumulative incidence function in the presence of competing risks. Statistical Software Components, Boston College Department of Economics. 2009. http://econpapers.repec.org/RePEc: boc:bocode:s457063.

17 AOANJRR. Australian Orthopaedic Association National Joint Replacement Registry, Annual Report. AOA, 2010.

18 World Health Organisation Global Health Observatory. Cancer mortality and morbidity. WHO, 2012. www.who.int/gho/ncd/mortality_morbidity/cancer_text/en/index.html.

19 Thomas E, Brewster DH, Black RJ, MacFarlane GJ. Risk of malignancy among patients with rheumatic conditions. Int J Cancer 2000;88:497-502.

20 Lie SA, Engesaeter LB, Havelin LI, Furnes O, Vollset SE. Mortality after total hip replacement: 0-10-year follow up of 39,543 patients in the Norwegian Arthroplasty Register. Acta Orthop Scand 2000;71:19-27.

21 Judge A, Welton NJ, Sandhu J, Ben-Shlomo Y. Equity in access to total joint replacement of the hip and knee in England: cross sectional study. BMJ 2010;341:c4092.

22 Visuri T, Pukkala E, Pulkkinen P, Paavolainen P. Decreased cancer risk in patients who have been operated on with total hip and knee arthroplasty for primary osteoarthrosis: a meta-analysis of 6 Nordic cohorts with 73,000 patients. Acta Orthop Scand 2003:74:351-60.

23 Lumb GD, Sunderman FW. The problem of latency in the development of tumors following exposure to nickel compounds. Sci Total Environ 1994;148:185-90.

24 Visuri T, Borg H, Pulkkinen P, Paavolainen P, Pukkala E. A retrospective comparative study of mortality and causes of death among patients with metal-on-metal and metal-on-polyethylene total hip prostheses in primary osteoarthritis after long-term follow-up. BMC Musculoskelet Disord 2010:11:78.

25 Haddad FS, Thakrar RR, Hart AJ, et al, Metal-on-metal bearings: the evidence so far. $J$ Bone Joint Surg Br 2011;93:572-9.

26 Hart AJ, Sabah SA, Bandi AS, Maggiore P, Tarassoli P, Sampson B, et al. Sensitivity and specificity of blood cobalt and chromium metal ions for predicting failure of metal-on-metal hip replacement. J Bone Joint Surg Br 2011;93:1308-13.

Accepted: 26 March 2012

\section{Cite this as: BMJ 2012;344:e2383}

This is an open-access article distributed under the terms of the Creative Commons Attribution Non-commercial License, which permits use, distribution, and reproduction in any medium, provided the original work is properly cited, the use is non commercial and is otherwise in compliance with the license. See: http://creativecommons.org/licenses/by$\mathrm{nc} / 2.0 /$ and http://creativecommons.org/licenses/by-nc/2.0/legalcode. 


\section{What is already known on this topic}

Metal-on-metal hip replacements produce metal particles that are disseminated throughout the body Though these metal particles can cause DNA damage, there is no proved link between this and an increased incidence of cancer Epidemiological studies are unclear as to whether metal-on-metal hip replacements are associated with an increase in cancers

\section{What this study adds}

In a large representative sample there was no association between metal-on-metal hip replacements and increased incidence of cancer in the first seven years after hip replacement

The one year incidence of cancer after total hip replacement is lower than that observed in the general population

\section{Tables}

\section{Table 1 | Characteristics of patients undergoing hip replacement. Figures are percentages of patients unless stated otherwise}

\begin{tabular}{|c|c|c|c|c|}
\hline & \multicolumn{2}{|c|}{ Metal-on-metal } & \multirow{2}{*}{$\begin{array}{l}\text { Other bearing surfaces } \\
\qquad(\mathrm{n}=248995)\end{array}$} & \multirow{2}{*}{$\begin{array}{l}\text { All hip replacement } \\
\qquad(\mathrm{n}=289571)\end{array}$} \\
\hline & Resurfacing ( $n=19$ 312) & Stemmed $(n=21264)$ & & \\
\hline Men & 67 & 52 & 37 & 40 \\
\hline Women & 33 & 48 & 63 & 60 \\
\hline \multicolumn{5}{|l|}{ Age (years): } \\
\hline$<45$ & 15 & 7 & 2 & 4 \\
\hline $45-54$ & 35 & 15 & 6 & 8 \\
\hline $55-64$ & 41 & 35 & 20 & 23 \\
\hline $65-74$ & 8 & 30 & 38 & 36 \\
\hline $75-84$ & 0.4 & 12 & 29 & 25 \\
\hline$\geq 85$ & 0 & 2 & 5 & 5 \\
\hline Mean age & 54.0 & 63.0 & 70.0 & 68.4 \\
\hline \multicolumn{5}{|l|}{ ASA grade: } \\
\hline 1-Fit and healthy & 46 & 25 & 16 & 19 \\
\hline 2-Mild systemic disease that does not limit activity & 51 & 62 & 68 & 67 \\
\hline $\begin{array}{l}\text { 3-Systemic disease that limits activity but is not } \\
\text { incapacitating }\end{array}$ & 4 & 12 & 15 & 14 \\
\hline $\begin{array}{l}\text { 4/5-Incapacitating, life threatening systemic disease/not } \\
\text { expected to survive } 24 \text { hours }\end{array}$ & 0.1 & 1 & 1 & 1 \\
\hline Mean ASA grade & 1.9 & 1.6 & 2.0 & 2.0 \\
\hline $\begin{array}{l}\text { Mean No of distinct diagnosis codes at time of hip } \\
\text { replacement }\end{array}$ & 2.0 & 2.8 & 3.0 & 2.9 \\
\hline Mean No of previous admissions to hospital & 2.3 & 3.3 & 3.7 & 3.5 \\
\hline
\end{tabular}

ASA=American Society of Anaesthesiologists. 


\begin{tabular}{|c|c|c|c|c|c|c|}
\hline \multicolumn{7}{|c|}{ Table 2| Incidence rates (\%) of new diagnosis of cancer for all patients who underwent hip replacement } \\
\hline & \multirow{2}{*}{$\begin{array}{c}\text { No excluded (previous } \\
\text { diagnosis) }\end{array}$} & \multirow[b]{2}{*}{ No at risk } & \multirow[b]{2}{*}{ Total time (years) observed } & \multirow[b]{2}{*}{ No with diagnosis } & \multicolumn{2}{|c|}{ Incidence rate $(95 \% \mathrm{Cl})$} \\
\hline & & & & & One year & Five years \\
\hline \multicolumn{7}{|c|}{ Stemmed metal-on-metal } \\
\hline Any cancer & 1078 & 20186 & 58338 & 653 & $1.00(0.87$ to 1.15$)$ & $5.65(5.13$ to 6.23$)$ \\
\hline Haematological cancer & 108 & 21156 & 61545 & 107 & $0.13(0.09$ to 0.19$)$ & $0.92(0.72$ to 1.17$)$ \\
\hline Malignant melanoma & 51 & 21213 & 61721 & 24 & $0.04(0.02$ to 0.08$)$ & $0.21(0.13$ to 0.33$)$ \\
\hline Prostate cancer & 185 & 10786 & 30435 & 117 & 0.35 (0.25 to 0.48$)$ & 1.92 (1.52 to 2.42 ) \\
\hline Renal cancer & 104 & 21160 & 61558 & 67 & $0.12(0.08$ to 0.18$)$ & 0.53 (0.39 to 0.73 ) \\
\hline \multicolumn{7}{|l|}{ Resurfacing } \\
\hline Any cancer & 372 & 18940 & 69358 & 445 & 0.50 (0.41 to 0.62$)$ & 3.34 (3.01 to 3.72 ) \\
\hline Haematological cancer & 46 & 19266 & 71131 & 55 & 0.05 (0.03 to 0.10$)$ & 0.41 (0.30 to 0.54$)$ \\
\hline Malignant melanoma & 28 & 19284 & 71253 & 20 & 0.02 (0.01 to 0.06$)$ & 0.12 (0.07 to 0.21$)$ \\
\hline Prostate cancer & 48 & 12882 & 45692 & 80 & 0.14 (0.09 to 0.22$)$ & 0.91 (0.71 to 1.16$)$ \\
\hline Renal cancer & 50 & 19262 & 71134 & 46 & 0.05 (0.03 to 0.10$)$ & 0.36 (0.26 to 0.49$)$ \\
\hline \multicolumn{7}{|l|}{ Other bearing surfaces } \\
\hline Any cancer & 16780 & 232215 & 686500 & 10845 & 1.34 (1.29 to 1.39$)$ & 8.17 (8.00 to 8.36$)$ \\
\hline Haematological cancer & 1769 & 247226 & 738237 & 1835 & 0.21 (0.19 to 0.23 ) & 1.31 (1.24 to 1.38$)$ \\
\hline Malignant melanoma & 722 & 248273 & 741432 & 415 & 0.05 (0.04 to 0.06$)$ & $0.28(0.25$ to 0.31$)$ \\
\hline Prostate cancer & 2917 & 88737 & 261665 & 1558 & 0.51 (0.47 to 0.57$)$ & 3.09 (2.91 to 3.27 ) \\
\hline Renal cancer & 2058 & 246937 & 737004 & 1088 & 0.11 (0.10 to 0.14$)$ & 0.76 (0.71 to 0.81$)$ \\
\hline \multicolumn{7}{|l|}{ All hip replacement } \\
\hline Any cancer & 18230 & 271341 & 814196 & 11945 & 1.25 (1.21 to 1.30$)$ & 7.58 (7.42 to 7.74$)$ \\
\hline Haematological cancer & 1923 & 287648 & 870914 & 1997 & $0.19(0.18$ to 0.21$)$ & 1.21 (1.15 to 1.27$)$ \\
\hline Malignant melanoma & 801 & 288770 & 874456 & 459 & 0.05 (0.04 to 0.06$)$ & 0.26 (0.23 to 0.29$)$ \\
\hline Prostate cancer & 3153 & 112405 & 337792 & 1755 & 0.45 (0.41 to 0.45$)$ & 2.68 (2.54 to 2.84 ) \\
\hline Renal cancer & 2212 & 287359 & 869696 & 1201 & 0.11 (0.10 to 0.12$)$ & $0.71(0.66$ to 0.76$)$ \\
\hline
\end{tabular}


Table 3/ Comparison of expected and observed incidence rates (\%) of cancer at one year for patients with hip replacement (with $95 \%$ confidence intervals)

\begin{tabular}{|c|c|c|c|c|}
\hline & \multicolumn{2}{|c|}{ Expected incidence rate* } & \multicolumn{2}{|c|}{ Observed incidence rate } \\
\hline & Men & Women & Men & Women \\
\hline All hip replacement & 1.91 (1.82 to 2.00$)$ & $1.48(1.42$ to 1.54$)$ & $1.46(1.39$ to 1.54$)$ & $1.11(1.06$ to 1.16$)$ \\
\hline Stemmed metal-on-metal & 1.45 (1.23 to 1.69$)$ & $1.22(1.02$ to 1.46$)$ & $1.15(0.96$ to 1.38$)$ & $0.84(0.68$ to 1.05$)$ \\
\hline Resurfacing & 0.77 (0.63 to 0.94$)$ & 0.73 (0.54 to 0.98$)$ & $0.48(0.37$ to 0.62$)$ & $0.56(0.40$ to 0.78$)$ \\
\hline Other bearing surfaces & 2.13 (2.05 to 2.22$)$ & $1.53(1.47$ to 1.59$)$ & 1.66 (1.57 to 1.76$)$ & $1.15(1.10$ to 1.21$)$ \\
\hline
\end{tabular}

*Based on national incidence rates. 


\begin{tabular}{|c|c|c|c|c|c|c|c|c|c|c|}
\hline \multirow[b]{2}{*}{ Variable } & \multicolumn{2}{|c|}{ All cancers } & \multicolumn{2}{|c|}{ Haematological } & \multicolumn{2}{|c|}{ Melanoma } & \multicolumn{2}{|c|}{ Prostate cancer } & \multicolumn{2}{|c|}{ Renal cancer } \\
\hline & $\begin{array}{l}\text { Hazard ratio } \\
(95 \% \mathrm{Cl})\end{array}$ & $P$ value & $\begin{array}{l}\text { Hazard ratio } \\
\qquad(95 \% \mathrm{Cl})\end{array}$ & $P$ value & $\begin{array}{l}\text { Hazard ratio } \\
\qquad(95 \% \mathrm{Cl})\end{array}$ & $P$ value & $\begin{array}{l}\text { Hazard ratio } \\
(95 \% \mathrm{Cl})\end{array}$ & $P$ value & $\begin{array}{l}\text { Hazard ratio } \\
\qquad(95 \% \mathrm{Cl})\end{array}$ & P value \\
\hline Men & $\begin{array}{c}1.57(1.51 \text { to } \\
1.62)\end{array}$ & $<0.001$ & $\begin{array}{c}1.40(1.28 \text { to } \\
1.53)\end{array}$ & $<0.001$ & $\begin{array}{c}1.31(1.08 \text { to } \\
1.58)\end{array}$ & 0.005 & - & - & $\begin{array}{c}3.30(2.93 \text { to } \\
3.72)\end{array}$ & $<0.001$ \\
\hline Age & $\begin{array}{c}1.04(1.04 \text { to } \\
1.04)\end{array}$ & $<0.001$ & $\begin{array}{c}1.04(1.03 \text { to } \\
1.04)\end{array}$ & $<0.001$ & $\begin{array}{c}1.03(1.02 \text { to } \\
1.04)\end{array}$ & $<0.001$ & $\begin{array}{c}1.07(1.06 \text { to } \\
1.07)\end{array}$ & $<0.001$ & $\begin{array}{c}1.05 \text { (1.05 to } \\
1.06)\end{array}$ & $<0.001$ \\
\hline $\begin{array}{l}\text { Stemmed } \\
\text { metal-on-metal }\end{array}$ & $\begin{array}{c}0.92(0.85 \text { to } \\
1.00)\end{array}$ & 0.038 & $\begin{array}{c}0.93(0.76 \text { to } \\
1.13)\end{array}$ & 0.465 & $\begin{array}{c}0.89(0.58 \text { to } \\
1.35)\end{array}$ & 0.569 & $\begin{array}{c}1.04(0.86 \text { to } \\
1.26)\end{array}$ & 0.688 & $\begin{array}{c}0.94(0.73 \text { to } \\
1.21)\end{array}$ & 0.618 \\
\hline Resurfacing & $\begin{array}{c}0.71(0.64 \text { to } \\
0.78)\end{array}$ & $<0.001$ & $\begin{array}{c}0.58(0.44 \text { to } \\
0.77)\end{array}$ & $<0.001$ & $\begin{array}{c}0.78(0.48 \text { to } \\
1.26)\end{array}$ & 0.312 & $\begin{array}{c}0.76(0.60 \text { to } \\
0.96)\end{array}$ & 0.022 & $\begin{array}{c}0.77(0.57 \text { to } \\
1.06)\end{array}$ & 0.109 \\
\hline $\begin{array}{l}\text { ASA } 1(v \text { ASA } \\
\text { 2) }\end{array}$ & $\begin{array}{c}0.88(0.84 \text { to } \\
0.93)\end{array}$ & $<0.001$ & $\begin{array}{c}0.87(0.77 \text { to } \\
0.99)\end{array}$ & 0.041 & $\begin{array}{c}0.91(0.71 \text { to } \\
1.17)\end{array}$ & 0.472 & $\begin{array}{c}1.05(0.92 \text { to } \\
1.19)\end{array}$ & 0.501 & $\begin{array}{c}0.81(0.67 \text { to } \\
0.96)\end{array}$ & 0.016 \\
\hline $\begin{array}{l}\text { ASA } 3(v \text { ASA } \\
\text { 2) }\end{array}$ & $\begin{array}{c}1.07(1.02 \text { to } \\
1.13)\end{array}$ & 0.006 & $\begin{array}{c}1.14(1.02 \text { to } \\
1.23)\end{array}$ & 0.026 & $\begin{array}{c}0.80(0.60 \text { to } \\
1.07)\end{array}$ & 0.129 & $\begin{array}{c}1.14(1.00 \text { to } \\
1.30)\end{array}$ & 0.050 & $\begin{array}{c}1.03(0.88 \text { to } \\
1.21)\end{array}$ & 0.704 \\
\hline $\begin{array}{l}\text { ASA 4-5 ( } v \\
\text { ASA 2) }\end{array}$ & $\begin{array}{c}0.88(0.70 \text { to } \\
1.11)\end{array}$ & 0.276 & $\begin{array}{c}1.28(0.82 \text { to } \\
2.00)\end{array}$ & 0.277 & $\begin{array}{c}1.25(0.46 \text { to } \\
3.38)\end{array}$ & 0.665 & $\begin{array}{c}0.94(0.54 \text { to } \\
1.64)\end{array}$ & 0.835 & $\begin{array}{c}1.00(0.53 \text { to } \\
1.87)\end{array}$ & 1.000 \\
\hline $\begin{array}{l}\text { No of diagnosis } \\
\text { codes }\end{array}$ & $\begin{array}{c}1.01(1.00 \text { to } \\
1.02)\end{array}$ & 0.005 & $\begin{array}{c}1.03(1.01 \text { to } \\
1.06)\end{array}$ & 0.003 & $\begin{array}{c}0.98(0.93 \text { to } \\
1.03)\end{array}$ & 0.415 & $\begin{array}{c}0.98(0.95 \text { to } \\
1.00)\end{array}$ & 0.080 & $\begin{array}{c}1.03(1.00 \text { to } \\
1.06)\end{array}$ & 0.024 \\
\hline $\begin{array}{l}\text { No of previous } \\
\text { admissions }\end{array}$ & $\begin{array}{c}1.02(1.01 \text { to } \\
1.02)\end{array}$ & $<0.001$ & $\begin{array}{c}1.03(1.02 \text { to } \\
1.03)\end{array}$ & $<0.001$ & $\begin{array}{c}1.02(1.00 \text { to } \\
1.04)\end{array}$ & 0.043 & $\begin{array}{c}1.01(1.00 \text { to } \\
1.02)\end{array}$ & 0.011 & $\begin{array}{c}1.02(1.01 \text { to } \\
1.03)\end{array}$ & 0.004 \\
\hline
\end{tabular}




\begin{tabular}{|c|c|c|c|c|c|c|c|c|c|c|}
\hline \multirow[b]{2}{*}{ Variable } & \multicolumn{2}{|l|}{ All } & \multicolumn{2}{|c|}{ Haematological } & \multicolumn{2}{|c|}{ Melanoma } & \multicolumn{2}{|c|}{ Prostate cancer } & \multicolumn{2}{|c|}{ Renal cancer } \\
\hline & $\begin{array}{l}\text { Subhazard } \\
\text { ratio }(95 \% \mathrm{Cl})\end{array}$ & $P$ value & $\begin{array}{l}\text { Subhazard ratio } \\
(95 \% \mathrm{Cl})\end{array}$ & $P$ value & $\begin{array}{l}\text { Subhazard ratio } \\
(95 \% \mathrm{Cl})\end{array}$ & $P$ value & $\begin{array}{l}\text { Subhazard } \\
\text { ratio }(95 \% \mathrm{Cl})\end{array}$ & $P$ value & $\begin{array}{l}\text { Subhazard ratio } \\
(95 \% \mathrm{Cl})\end{array}$ & $P$ value \\
\hline Men & $\begin{array}{c}1.40(1.35 \text { to } \\
1.46)\end{array}$ & $<0.001$ & $\begin{array}{c}1.41(1.37 \text { to } \\
1.45)\end{array}$ & $<0.001$ & $\begin{array}{c}1.39(1.35 \text { to } \\
1.43)\end{array}$ & $<0.001$ & - & - & $\begin{array}{c}1.38(1.34 \text { to } \\
1.42)\end{array}$ & $<0.001$ \\
\hline Age & $\begin{array}{c}1.09(1.09 \text { to } \\
1.10)\end{array}$ & $<0.001$ & $\begin{array}{c}1.08(1.07 \text { to } \\
1.08)\end{array}$ & $<0.001$ & $\begin{array}{c}1.07(1.07 \text { to } \\
1.08)\end{array}$ & $<0.001$ & $\begin{array}{c}1.07(1.07 \text { to } \\
1.07)\end{array}$ & $<0.001$ & $\begin{array}{c}1.07(1.07 \text { to } \\
1.08)\end{array}$ & $<0.001$ \\
\hline $\begin{array}{l}\text { Stemmed } \\
\text { metal-on-metal }\end{array}$ & $\begin{array}{c}1.02(0.93 \text { to } \\
1.12)\end{array}$ & 0.618 & $\begin{array}{c}0.96(0.89 \text { to } \\
1.04)\end{array}$ & 0.316 & $\begin{array}{c}0.94(0.88 \text { to } \\
1.01)\end{array}$ & 0.115 & $\begin{array}{c}0.83(0.76 \text { to } \\
0.89)\end{array}$ & $<0.001$ & $\begin{array}{c}0.95(0.88 \text { to } \\
1.02)\end{array}$ & 0.169 \\
\hline Resurfacing & $\begin{array}{c}0.72(0.61 \text { to } \\
0.86)\end{array}$ & $<0.001$ & $\begin{array}{c}0.58(0.51 \text { to } \\
0.67)\end{array}$ & $<0.001$ & $\begin{array}{c}0.55(0.48 \text { to } \\
0.63)\end{array}$ & $<0.001$ & $\begin{array}{c}1.62(1.53 \text { to } \\
1.71)\end{array}$ & $<0.001$ & $\begin{array}{c}0.55(0.48 \text { to } \\
0.63)\end{array}$ & $<0.001$ \\
\hline $\begin{array}{l}\text { ASA } 1 \text { ( } v \text { ASA } \\
\text { 2) }\end{array}$ & $\begin{array}{c}0.83(0.78 \text { to } \\
0.89)\end{array}$ & $<0.001$ & $\begin{array}{c}0.83(0.79 \text { to } \\
0.87)\end{array}$ & $<0.001$ & $\begin{array}{c}0.83(0.79 \text { to } \\
0.88)\end{array}$ & $<0.001$ & $\begin{array}{c}1.00(0.90 \text { to } \\
1.10)\end{array}$ & 0.968 & $\begin{array}{c}0.83(0.79 \text { to } \\
0.87)\end{array}$ & $<0.001$ \\
\hline $\begin{array}{l}\text { ASA } 3 \text { ( } v \text { ASA } \\
\text { 2) }\end{array}$ & $\begin{array}{c}1.73(1.65 \text { to } \\
1.80)\end{array}$ & $<0.001$ & $\begin{array}{c}1.66(1.60 \text { to } \\
1.72)\end{array}$ & $<0.001$ & $\begin{array}{c}1.65(1.60 \text { to } \\
1.71)\end{array}$ & $<0.001$ & $\begin{array}{c}0.56(0.48 \text { to } \\
0.66))\end{array}$ & $<0.001$ & $\begin{array}{c}1.65(1.60 \text { to } \\
1.71)\end{array}$ & $<0.001$ \\
\hline $\begin{array}{l}\text { ASA 4-5 ( } v \\
\text { ASA 2) }\end{array}$ & $\begin{array}{c}2.63(2.34 \text { to } \\
2.96)\end{array}$ & $<0.001$ & $\begin{array}{c}2.66(2.41 \text { to } \\
2.93)\end{array}$ & $<0.001$ & $\begin{array}{c}2.74(2.51 \text { to } \\
3.01)\end{array}$ & $<0.001$ & $\begin{array}{c}2.62(2.27 \text { to } \\
3.03)\end{array}$ & $<0.001$ & $\begin{array}{l}2.74(2.50 \text { to } \\
3.01)\end{array}$ & $<0.001$ \\
\hline $\begin{array}{l}\text { No of diagnosis } \\
\text { codes }\end{array}$ & $\begin{array}{c}1.12(1.12 \text { to } \\
1.13)\end{array}$ & $<0.001$ & $\begin{array}{c}1.11(1.11 \text { to } \\
1.12)\end{array}$ & $<0.001$ & $\begin{array}{c}1.11(1.11 \text { to } \\
1.12)\end{array}$ & $<0.001$ & $\begin{array}{c}1.12(1.12 \text { to } \\
1.13)\end{array}$ & $<0.001$ & $\begin{array}{c}1.11(1.11 \text { to } \\
1.12)\end{array}$ & $<0.001$ \\
\hline $\begin{array}{l}\text { No of previous } \\
\text { admissions }\end{array}$ & $\begin{array}{c}1.04(1.04 \text { to } \\
1.05)\end{array}$ & $<0.001$ & $\begin{array}{c}1.04(1.04 \text { to } \\
1.04)\end{array}$ & $<0.001$ & $\begin{array}{c}1.04(1.04 \text { to } \\
1.04)\end{array}$ & $<0.001$ & $\begin{array}{c}1.03(1.03 \text { to } \\
1.04)\end{array}$ & $<0.001$ & $\begin{array}{c}1.04(1.04 \text { to } \\
1.04)\end{array}$ & $<0.001$ \\
\hline
\end{tabular}


Table $6 \mid$ Predicted cumulative incidence $(\%)^{\star}$ of cancer after hip replacement by bearing surface for typical patient aged 60

\begin{tabular}{llllll} 
& \multicolumn{1}{c}{ Year $\mathbf{1}$} & Year $\mathbf{2}$ & Year 3 & Year 4 & Year 5 \\
\hline Men & & & & & \\
\hline Resurfacing & $0.8(0.7$ to 0.9$)$ & $1.8(1.6$ to 1.9$)$ & $2.7(2.5$ to 2.9$)$ & $3.7(3.4$ to 4.1$)$ & $4.8(4.4$ to 5.3$)$ \\
\hline Stemmed metal-on-metal & $1.1(0.9$ to 1.2$)$ & $2.3(2.1$ to 2.5$)$ & $3.5(3.3$ to 3.8$)$ & $4.8(4.5$ to 5.2$)$ & $6.2(5.7$ to 6.7$)$ \\
\hline Other bearing surfaces & $1.2(1.1$ to 1.2$)$ & $2.5(2.4$ to 2.6$)$ & $3.9(3.7$ to 4.0$)$ & $5.3(5.1$ to 5.5$)$ & $6.7(6.5$ to 7.0$)$ \\
\hline Women & & & & & \\
\hline Resurfacing & $0.5(0.5$ to 0.6$)$ & $1.1(1.0$ to 1.2$)$ & $1.8(1.6$ to 1.9$)$ & $2.4(2.2$ to 2.6$)$ & $3.1(2.8$ to 3.4$)$ \\
\hline Stemmed metal-on-metal & $0.7(0.6$ to 0.7$)$ & $1.5(1.4$ to 1.6$)$ & $2.3(2.1$ to 2.5$)$ & $3.1(2.9$ to 3.4$)$ & $4.0(3.7$ to 4.3$)$ \\
\hline Other bearing surfaces & $0.7(0.7$ to 0.8$)$ & $1.6(1.5$ to 1.7$)$ & $2.5(2.4$ to 2.6$)$ & $3.4(3.3$ to 3.5$)$ & $4.4(4.2$ to 4.5$)$ \\
\hline
\end{tabular}

${ }^{*}$ Results estimated from multivariable competing risks flexible parametric survival models based on 21264 stemmed metal-on-metal cases, 19312 resurfacing procedures, and 248995 hip replacements with other bearing surfaces. Values of model covariates are held constant at age 60, ASA grade of 2, two previous admissions, and three diagnosis codes at admission. 